\title{
NEW CHRONOLOGICAL FRAME FOR THE YOUNG NEOLITHIC BADEN CULTURE IN CENTRAL EUROPE (4TH MILLENNIUM BC)
}

\author{
Eva Maria Wild ${ }^{1,2} \bullet$ Peter Stadler ${ }^{3,4} \bullet$ Mária Bondár $^{5} \bullet$ Susanne Draxler $^{1} \bullet$ Herwig Friesinger $^{4} \bullet$ \\ Walter Kutschera ${ }^{1} \bullet{\text { Alfred } \text { Priller }^{1} \bullet \text { Werner Rom }^{1} \bullet \text { Elisabeth Ruttkay }}^{3} \bullet$ Peter Steier ${ }^{1}$
}

\begin{abstract}
The Baden Culture is a widely spread culture of the Young Neolithics in east-central Europe. In southeast Europe, several parallel cultures are found at different places. The main innovations in east-central Europe associated with the Baden Culture were traditionally thought to originate in southeast Europe, Anatolia, and the Levant. However, in recent years, doubt about this theory has arisen among archaeologists.

Here, we try to contribute to this question by increasing the radiocarbon data set available for the Baden Culture. Thirty-two age determinations of samples from different sites assigned to the Baden Culture were performed by accelerator mass spectrometry (AMS) ${ }^{14} \mathrm{C}$ dating. The new data were combined with previously published ${ }^{14} \mathrm{C}$ dates. Data from the individual cultural phases of the entire Baden period and the parallel cultures in southeast Europe (Sitagroi, Cernavoda, and Ezero) were analyzed by sum calibration. Comparison of the results indicates that the southeastern cultures cannot be synchronized with the Boleráz period, the early phase of the Baden Culture. It seems that these cultures were parallel to the Baden Classical period. This finding, which has to be verified by more data from the southeastern cultures, contradicts the theory of the eastwest spreading of these cultures.
\end{abstract}

\section{INTRODUCTION}

During the Young Neolithic period around 4250-2850 BC (according to the central European chronology) principal progress was made in various fields of cultural and economic life. In this period we find the first occurrence of wheeled vehicles, an enormous step forward in the cultural development and exchange systems. The importance of this innovation is documented by models of wagons made from ceramics found as grave goods. In central Europe, a change occurred in the species of domestic sheep to a bigger form of wool sheep that was probably raised in the Anatolian region. The decoration of ceramics originating from this period shows that typical characteristics and similar features are found in various sites throughout southeast Europe (Kalicz 1963; Nĕmejcová-Pavúková 1981). Archaeologists had assumed that the origin of these cultural innovations was in southeast Europe, Anatolia, and the Levant. It was believed that they spread from there to east-central Europe. However, over the last few years, archaeologists have begun to doubt this theory (Breunig 1987; Maran 1998).

Using radiocarbon dating, we compared the time periods of some of the so-called parallel cultures in southeast Europe with the chronology of the Baden Culture in east-central Europe.

\section{The Baden Culture}

The Baden Culture is a widely spread Young Neolithic culture in east-central Europe. It is named after the "Königshöhle" near Baden, Lower Austria, where the remains of this culture were discovered for the first time.

\footnotetext{
${ }^{1}$ Vienna Environmental Research Accelerator (VERA), Institut für Isotopenforschung und Kernphysik, Universität Wien, Währinger Strasse 17, A-1090 Wien, Austria

${ }^{2}$ Corresponding author. Email: eva.maria.wild@univie.ac.at.

${ }^{3}$ Prähistorische Abteilung, Naturhistorisches Museum, Burgring 7, A-1010 Wien, Austria

${ }^{4}$ Institut für Ur- und Frühgeschichte, Universität Wien, Franz Klein Gasse 1, A-1190 Wien, Austria

${ }^{5}$ Archaeological Institute of the Hungarian Academy of Sciences, Úri utca 49, H-1014 Budapest, Hungary
}

(C) 2001 by the Arizona Board of Regents on behalf of the University of Arizona

Radiocarbon, Vol 43, Nr 2B, 2001, p 1057-1064

Proceedings of the 17th International ${ }^{14} \mathrm{C}$ Conference, edited by I Carmi and $\mathrm{E}$ Boaretto 
The Baden Culture is characterized by a typical design of pottery. As in the other Young Neolithic cultures, Baden people already used wheeled vehicles. Ceramic models of wagons were found in graves from the Baden period in Hungary (e.g. Foltiny 1959; Kalicz 1976). During the Baden period, the burial mode had been changed from cremation to burial of the body with funeral rites. The earliest signature of a trephination found so far in Austria was on a skull from the period of the Baden Culture (Heiling-Schmoll 1985).

\section{Phases of the Baden Culture}

The Baden Culture is divided into two large phases. The earlier one is called Baden-Boleráz after the locus typicus near Trnava in Slovakia. Ceramics from this period typically have brown surfaces in different shades and are decorated with herring-bone patterns. The Baden-Boleráz phase is followed by the so-called Baden-Classical period. One of the main characteristics of ceramics from that period is mugs with dark surfaces and handles extending far above the rim.

Archaeological evidence shows that the two main stages were further divided into a number of consecutive phases of development (Baden Ia-c, IIa-b, III, IVa), which are characterized by, among other things, a specific design of the associated pottery (Němejcová-Pavúková 1998). The Boleráz group was thought to occur later than the Proto-Boleráz group of Šturovo (Baden Ia) in Slovakia (Kalicz 1991).

In the Boleráz period, three phases were differentiated (Baden Ib-Ic-IIa). The Baden Classical period was subdivided into three groups: Červeny-Hradok (Slovakia, Baden IIb), Ossarn I (Baden III), and Ossarn II (Baden IVa), named after a site in Lower Austria (Ruttkay 1995).

\section{Parallel Cultures}

In southeastern Europe, cultures with characteristics similar to those of the Baden Culture are found in Romania (Cernavoda III), Greece (Sitagroi IV and Vb), and Bulgaria (Ezeroi XIII-VII). At Tell Dipsis in Ezero, Bulgaria, 13 strata were identified, and the culture encompassing strata XIII-VII was synchronized with the Boleráz period by Nĕmejcová-Pavúková (1981).

Sitagroi-also a tell settlement-is a key archaeological site in northern Greece. The archaeological layers of this site are associated with five cultural phases (Renfrew 1971, 1986; Alram-Stern 1996). Ceramics from phases IV and Vb show similarities to the pottery from the Baden Culture and the Late Baden Culture, respectively (Breunig 1987).

In Romania, the Cernavoda site is archaeologically classified into the chronological sequence Cernavoda I-III-II, where the individual Roman numerals correspond to different places at the Cernavoda location. The Cernavoda III period was estimated to be parallel to the Boleráz period (Morintz and Roman 1968; Roman 1999; Maran 1998; Nĕmejcová-Pavúková 1999).

\section{${ }^{14} \mathrm{C}$-Dating of the Baden Culture and Parallel Cultures}

The Vienna Environmental Research Accelerator (VERA) laboratory is engaged in a larger interdisciplinary project, "Absolute Chronology for Early Civilisations in Austria and Central Europe using Accelerator Mass Spectrometry". In the course of this project, the Baden Culture and its relation to the parallel cultures is investigated. Thirty-two samples from various sites of the Baden Culture, mainly bones but also charcoals, were selected according to archaeological evidence and ${ }^{14} \mathrm{C}$ dated by the accelerator mass spectrometry (AMS) method at VERA. 
Bone samples were decalcified and gelatin was produced from the organic substance. For the pretreatment of the samples an automatic collagen extraction apparatus similar to the one developed by Law and Hedges (1989) was used. Charcoal samples were treated manually by the standard ABA method. Further processing and measurement of the cleaned samples is described in Wild et al. (1998). Since then, we changed from mounting duplicates and triplicates (targets with identical target material) of all samples into our 40-position target wheel to the use of only two duplicates of the C-3 IAEA ${ }^{14} \mathrm{C}$-standard. The purpose of the multiple targets at different positions was to compensate for small position dependency problems, which turned out to originate from a slight eccentricity of the target wheel. We now use the two standard duplicates distributed at opposite positions around the wheel to monitor eccentricity effects. Small eccentricity effects can be corrected mathematically by using the measured ${ }^{14} \mathrm{C} /{ }^{12} \mathrm{C}$ and the ${ }^{13} \mathrm{C} /{ }^{12} \mathrm{C}$ ratio of the identical targets. Larger eccentricity effects require a retuning of the machine. During the measurement, data are automatically evaluated by a computer program, which allows an online check of various diagnostic marks. Details of this program are described in Puchegger et al. (2000). The ${ }^{14} \mathrm{C}$ ages of the samples calculated according to Stuiver and Polach (1977) are converted to calibrated ages with the OxCal calibration program (Bronk Ramsey 2000).

With the ${ }^{14} \mathrm{C}$ ages determined at VERA and the 43 ages found in the literature, a data set of 75 dates is now available for the Baden Culture period. Table 1 lists the complete data. From this data set, the data of the different phases in east-central Europe were grouped and analyzed by sum calibration with OxCal. With this option of the calibration program, the probability distributions of all events assigned to a single phase of a cultural period can be summed up, giving each event the same weight. The result is a new probability distribution that gives a best estimate of the chronological distribution of the dated events (Bronk Ramsey 1999). In other words, if the data set is sufficiently large, the $68 \%$ probability range of such a distribution means that $68 \%$ of the total events fall within this time interval. This implies that the $68 \%$ time interval of the sum calibration allows significant conclusions, whereas this is not possible for the $1-\sigma$ interval of the calibration of single events.

Table 2 shows the $68 \%$ and $95 \%$ intervals of the sum calibration for the individual phases of the Baden culture. These results were compared with those of sum calibration performed for the southeastern cultures displayed in Table 3.

\section{DISCUSSION}

For interpretation of the results of the sum calibration, only the time periods corresponding to the $68 \%$ confidence level are considered. This seems to be a useful way to reduce the influence of outliers in a data set of the investigated cultural period. A few such samples in a data set of a cultural phase with ages much younger or older than the investigated period would cause a broadening of the $95 \%$ interval of the sum distribution, but would have little effect on the $68 \%$ time period. As described above, the $68 \%$ time period of the sum calibration allows a significant assessment of a cultural phase.

For the Proto-Boleráz, a $68 \%$ time period from 3630 to $3360 \mathrm{BC}$ was determined. This period is nearly identical with the period determined for the Boleráz phase. Although an overlap exists between the Červeny Hradok and the Boleráz time, the younger phases of the Baden-Classical period can be distinguished from the Boleráz by sum calibration.

Overlaps of the individual time intervals are found for the sequence Červeny Hradok-Ossarn IOssarn II. This sequence cannot be resolved with the sum calibration of the ${ }^{14} \mathrm{C}$ ages. The calibration curve shows a small plateau in this time period. We must also note that for the Cerveny Hradok and Ossarn II phases, only five samples were analyzed. A larger data set for these two phases would be more informative. 
Table 1 Currently available data for the Baden and the parallel cultures. For more detailed information on these data, see Stadler et al. (2000).

\begin{tabular}{|c|c|c|c|c|c|c|c|}
\hline Country & Site & Lab code & Material & $\begin{array}{c}{ }^{14} \mathrm{C} \text { age } \\
\text { (BP) }\end{array}$ & $\begin{array}{l}1-\sigma \\
\text { error }\end{array}$ & Culture & Reference for the site \\
\hline YU & Gomolova & GrN-13168 & Charcoal & 4380 & 70 & Baden & Forenbaher 1993 \\
\hline $\mathrm{H}$ & Ószentiván & Bln-476 & Charcoal & 4515 & 80 & Baden & Bojadžiev 1992 \\
\hline SK & Podolie & Bln-556 & Charcoal & 4455 & 80 & Baden & Forenbaher 1993 \\
\hline $\mathrm{H}$ & Sümeg & A-246 & —a $^{\mathrm{a}}$ & 4520 & 60 & Baden & Forenbaher 1993 \\
\hline $\mathrm{H}$ & Szigetcsép & Bln-1637 & - & 4350 & 45 & Baden & Forenbaher 1993 \\
\hline A & Niederhollabrunn & ETH-15241 & Bone, human & 4710 & 95 & Baden? & Lauermann 1996 \\
\hline RO & Cernavoda I & $B \ln -61$ & - & 4385 & 100 & Parallel culture & Breunig 1987 \\
\hline RO & Cernavoda I & Bln-61a & - & 4505 & 100 & Parallel culture & Breunig 1987 \\
\hline RO & Cernavoda I & Bln-62 & - & 4260 & 100 & Parallel culture & Breunig 1987 \\
\hline RO & Cernavoda I & Bln-1061 & - & 4710 & 100 & Parallel culture & Görsdorf 2000 \\
\hline BG & Ezero & Bln-421 & Seed & 4335 & 80 & Parallel culture & Görsdorf 1996 \\
\hline BG & Ezero & Bln- 422 & Charcoal & 4310 & 80 & Parallel culture & Görsdorf 1996 \\
\hline BG & Ezero & $B \ln -427$ & Charcoal & 4365 & 80 & Parallel culture & Görsdorf 1996 \\
\hline BG & Ezero & $B \ln -428$ & Seed & 4260 & 80 & Parallel culture & Görsdorf 1996 \\
\hline BG & Ezero & $B \ln -429$ & Seed & 4130 & 100 & Parallel culture & Görsdorf 1996 \\
\hline BG & Ezero & Bln-1822 & Charcoal & 4275 & 65 & Parallel culture & Görsdorf 1996 \\
\hline BG & Ezero & Bln-1824 & Seed & 4135 & 65 & Parallel culture & Görsdorf 1996 \\
\hline GR & Sitagroi IV & Bln-773 & Seed & 4390 & 100 & Parallel culture & Breunig 1987 \\
\hline GR & Sitagroi IV & Bln-782 & Charcoal & 4310 & 100 & Parallel culture & Breunig 1987 \\
\hline GR & Sitagroi IV & Bln- 878 & Charcoal & 4395 & 100 & Parallel culture & Breunig 1987 \\
\hline GR & Sitagroi IV & Bln-879 & Charcoal & 4550 & 100 & Parallel culture & Breunig 1987 \\
\hline GR & Sitagroi IV & Bln-880 & Seed & 4510 & 100 & Parallel culture & Breunig 1987 \\
\hline GR & Sitagroi IV & BM 650a & Charcoal & 4363 & 56 & Parallel culture & Breunig 1987 \\
\hline GR & Sitagroi IV & BM 651 & Seed & 4332 & 79 & Parallel culture & Breunig 1987 \\
\hline $\mathrm{CH}$ & Arbon Bleiche & B-6360 & Charcoal & 4710 & 30 & Baden-Boleráz & Leuzinger 1999 \\
\hline $\mathrm{CH}$ & Arbon Bleiche & B-6361 & Harcoal & 4700 & 30 & Baden-Boleráz & Leuzinger 1999 \\
\hline $\mathrm{CH}$ & Arbon Bleiche & B-6362 & Charcoal & 4640 & 30 & Baden-Boleráz & Leuzinger 1999 \\
\hline $\mathrm{CH}$ & Arbon Bleiche & B-6363 & Charcoal & 4690 & 30 & Baden-Boleráz & Leuzinger 1999 \\
\hline $\mathrm{CH}$ & Arbon Bleiche & B-6364 & Charcoal & 4620 & 40 & Baden-Boleráz & Leuzinger 1999 \\
\hline $\mathrm{CH}$ & Arbon Bleiche & B-6365 & Charcoal & 4660 & 40 & Baden-Boleráz & Leuzinger 1999 \\
\hline A & Baierdorf & VERA-838 & Bone, animal & 4645 & 35 & Baden-Boleráz & Ruttkay 1998 \\
\hline A & Grub an der March & VERA-876 & Bone, animal & 4770 & 55 & Baden-Boleráz & Krenn-Leeb 1991 \\
\hline A & Grub an der March & VERA-877 & Bone, Animal & 4760 & 50 & Baden-Boleráz & Krenn-Leeb 1991 \\
\hline A & Grub an der March & VERA-878 & Bone, animal & 4790 & 55 & Baden-Boleráz & Krenn-Leeb 1991 \\
\hline $\mathrm{H}$ & Gyöngyöshalász & Bln-2589 & Charcoal & 4790 & 50 & Baden-Boleráz & Szabó 1983 \\
\hline $\mathrm{CZ}$ & Hlinsko & Bln-3232 & - & 4780 & 70 & Baden-Boleráz & Pavelčík 1992 \\
\hline $\mathrm{CZ}$ & Hlinsko & Bln-3233 & - & 4680 & 60 & Baden-Boleráz & Pavelčík 1992 \\
\hline $\mathrm{CZ}$ & Hlinsko & GrN-13149 & - & 4750 & 60 & Baden-Boleráz & Pavelčík 1992 \\
\hline $\mathrm{CZ}$ & Hlinsko & GrN-16728 & - & 4650 & 40 & Baden-Boleráz & Pavelčík 1992 \\
\hline $\mathrm{CZ}$ & Hlinsko & GrN-16729 & - & 4605 & 40 & Baden-Boleráz & Pavelčík 1992 \\
\hline A & Schwechat & VERA-849 & Bone, animal & 4935 & 45 & Baden-Boleráz & Ruttkay 1971 \\
\hline $\mathrm{H}$ & Szihalom & VERA-852 & Bone, animal & 4785 & 40 & Baden-Boleráz & Szabó 1997 \\
\hline $\mathrm{H}$ & Szihalom & VERA-853 & Bone, animal & 4740 & 40 & Baden-Boleráz & Szabó 1997 \\
\hline $\mathrm{H}$ & Szihalom & VERA-854 & Bone, animal & 4830 & 40 & Baden-Boleráz & Szabó 1997 \\
\hline $\mathrm{H}$ & Szihalom & VERA-855 & Bone, animal & 4850 & 60 & Baden-Boleráz & Szabó 1997 \\
\hline $\mathrm{H}$ & Szihalom & VERA-856 & Bone, animal & 4785 & 35 & Baden-Boleráz & Szabó 1997 \\
\hline $\mathrm{H}$ & Szihalom & VERA-857 & Bone, animal & 4755 & 35 & Baden-Boleráz & Szabó 1997 \\
\hline $\mathrm{H}$ & Szihalom & VERA-862 & Charcoal & 4735 & 35 & Baden-Boleráz & Szabó 1997 \\
\hline $\mathrm{H}$ & Szihalom & VERA-863 & Charcoal & 4745 & 35 & Baden-Boleráz & Szabó 1997 \\
\hline A & Zillingtal & VERA-860 & Bone, animal & 4625 & 35 & Baden-Boleráz & Heiling-Schmoll 1985 \\
\hline A & Zillingtal & VERA-861 & Bone, animal & 4700 & 45 & Baden-Boleráz & Heiling-Schmoll 1985 \\
\hline
\end{tabular}


Table 1 Currently available data for the Baden and the parallel cultures. More detailed information on these data is given in Stadler et al. (2000). (Continued)

\begin{tabular}{|c|c|c|c|c|c|c|c|}
\hline Country & Site & Lab code & Material & $\begin{array}{l}{ }^{14} \mathrm{C} \text { age } \\
\text { (BP) }\end{array}$ & $\begin{array}{l}1-\sigma \\
\text { error }\end{array}$ & Culture & Reference for the site \\
\hline SK & Bajc-Vlkanovo & VERA-736 & Charcoal & 4530 & 45 & $\begin{array}{l}\text { Classical Baden- } \\
\text { Červený Hradok }\end{array}$ & Nevizánsky 1984 \\
\hline SK & Červený Hrádok & GrN-11994 & 一 $^{\mathrm{a}}$ & 4390 & 70 & $\begin{array}{l}\text { Classical Baden- } \\
\text { Červený Hradok }\end{array}$ & $\begin{array}{l}\text { Nĕmejcová- } \\
\text { Pavúková } 1985\end{array}$ \\
\hline A & $\begin{array}{l}\text { Ossarn Stickel- } \\
\text { berger }\end{array}$ & GrN-6940 & - & 4520 & 40 & $\begin{array}{l}\text { Classical Baden- } \\
\text { Červený Hradok }\end{array}$ & Mayer 1995b \\
\hline A & Stillfried & VERA-850 & Charcoal & 4605 & 35 & $\begin{array}{l}\text { Classical Baden- } \\
\text { Červený Hradok }\end{array}$ & Schappelwein 1994 \\
\hline A & Stillfried & VERA-851 & Charcoal & 4645 & 35 & $\begin{array}{l}\text { Classical Baden- } \\
\text { Červený Hradok }\end{array}$ & Schappelwein 1994 \\
\hline $\mathrm{CZ}$ & Beladice & Bln-2171 & - & 4420 & 60 & Baden-Ossarn I & Forenbaher 1993 \\
\hline PL & Iwanowice & Bln-352 & - & 4200 & 100 & Baden-Ossarn I & Bogucki 1992 \\
\hline PL & Iwanowice & M-2166 & Charcoal & 4300 & 200 & Baden-Ossarn I & Breunig 1987 \\
\hline $\mathrm{H}$ & Nagykanizsa & VERA-840 & Bone, animal & 4455 & 50 & Baden-Ossarn I & Barna Judith 2000 \\
\hline $\mathrm{H}$ & Nagykanizsa & VERA-841 & Bone, animal & 4425 & 40 & Baden-Ossarn I & Barna Judith 2000 \\
\hline $\mathrm{H}$ & Nagykanizsa & VERA-843 & Bone, animal & 4400 & 40 & Baden-Ossarn I & Barna Judith 2000 \\
\hline $\mathrm{H}$ & Nagykanizsa & VERA-844 & Bone, animal & 4425 & 35 & Baden-Ossarn I & Barna Judith 2000 \\
\hline $\mathrm{H}$ & Nagykanizsa & VERA-846 & Bone, animal & 4080 & 40 & Baden-Ossarn I & Barna Judith 2000 \\
\hline A & Pottenbrunn & GrN-14016 & Charcoal? & 4560 & 40 & Baden-Ossarn I & Mayer 1995a \\
\hline SK & Šarišské Michalany & VERA-769 & Charcoal & 4385 & 35 & Baden-Ossarn I & Šiška unpublished \\
\hline A & Straß im Straßertale & VERA-893 & Bone, animal & 4515 & 45 & Baden-Ossarn I & Wewerka 1995 \\
\hline SK & Svodín & Bln-2173 & - & 4460 & 60 & Baden-Ossarn I & Forenbaher 1993 \\
\hline $\mathrm{H}$ & Vámosgyörk & VERA-903 & Bone, human & 4475 & 45 & Baden-Ossarn I & Farkas unpublished \\
\hline $\mathrm{H}$ & Vámosgyörk & VERA-904 & Bone, human & 4400 & 45 & Baden-Ossarn I & Farkas unpublished \\
\hline YU & Vučedol & Z-1446 & Charcoal & 4540 & 86 & Baden-Ossarn I & Forenbaher 1993 \\
\hline YU & Vučedol & Z-1466 & - & 4540 & 130 & Baden-Ossarn I & Ehrich 1992 \\
\hline YU & Vučedol & Z-1617 & Charcoal & 4500 & 100 & Baden-Ossarn I & Bojadžiev 1992 \\
\hline YU & Vučedol & Z-1618 & Charcoal & 4300 & 100 & Baden-Ossarn I & Bojadžiev 1992 \\
\hline YU & Vučedol & Z-1619 & Charcoal & 4400 & 100 & Baden-Ossarn I & Bojadžiev 1992 \\
\hline YU & Vučedol & Z-1864 & Bone & 4626 & 100 & Baden-Ossarn I & Forenbaher 1993 \\
\hline A & Franzhausen & VERA-868 & Bone, human & 4510 & 40 & Baden-Ossarn-I & Neugebauer 1998 \\
\hline A & Girm & VERA-869 & Bone, animal & 4530 & 50 & Baden-Ossarn-I & Böhm 2000 \\
\hline A & Girm & VERA-875 & Bone, animal & 4565 & 45 & Baden-Ossarn-I & Böhm 2000 \\
\hline A & Hadersdorf & VERA-880 & Bone, animal & 4510 & 45 & Baden-Ossarn-I & Wewerka unpub. \\
\hline A & Hadersdorf & VERA-881 & Bone, animal & 4485 & 40 & Baden-Ossarn-I & Wewerka unpub. \\
\hline A & Lichtenwörth & Bln-2069 & - & 4540 & 45 & Baden-Ossarn-II & Mayer 1995a \\
\hline A & Lichtenwörth & Bln-2070 & - & 4530 & 70 & Baden-Ossarn-II & Mayer 1995a \\
\hline A & Lichtenwörth & Bln-2071 & - & 4410 & 60 & Baden-Ossarn-II & Mayer 1995a \\
\hline SK & Svodín & Bln-2169 & - & 4270 & 50 & Baden-Ossarn-II & Bojadžiev 1992 \\
\hline SK & Svodín & Bln-2174 & Charcoal & 4390 & 60 & Baden-Ossarn-II & Bojadžiev 1992 \\
\hline SK & Červený Hrádok & GrN-11992 & - & 4820 & 70 & $\begin{array}{l}\text { Baden-Šturovo- } \\
\text { Protoboleráz }\end{array}$ & $\begin{array}{l}\text { Nĕmejcová- } \\
\text { Pavúková } 1984\end{array}$ \\
\hline SK & Červený Hrádok & GrN-11993 & - & 4710 & 100 & $\begin{array}{l}\text { Baden-Šturovo- } \\
\text { Protoboleráz }\end{array}$ & $\begin{array}{l}\text { Nĕmejcová- } \\
\text { Pavúková } 1984\end{array}$ \\
\hline $\mathrm{CZ}$ & Hlinsko & Bln-1165 & - & 4670 & 80 & $\begin{array}{l}\text { Baden-Šturovo- } \\
\text { Protoboleráz }\end{array}$ & Pavelèík 1992 \\
\hline $\mathrm{CZ}$ & Hlinsko & Bln-1166 & - & 4670 & 80 & $\begin{array}{l}\text { Baden-Šturovo- } \\
\text { Protoboleráz }\end{array}$ & Pavelčík 1992 \\
\hline $\mathrm{CZ}$ & Hlinsko & Bln-1396 & - & 4775 & 60 & $\begin{array}{l}\text { Baden-Šturovo- } \\
\text { Protoboleráz }\end{array}$ & Pavelčík 1992 \\
\hline $\mathrm{CZ}$ & Hlinsko & GrN-6941 & - & 4670 & 40 & $\begin{array}{l}\text { Baden-Šturovo- } \\
\text { Protoboleráz }\end{array}$ & Pavelčík 1992 \\
\hline $\mathrm{CZ}$ & Hlinsko & GrN-6942 & - & 4670 & 45 & $\begin{array}{l}\text { Baden-Šturovo- } \\
\text { Protoboleráz }\end{array}$ & Pavelčík 1992 \\
\hline
\end{tabular}

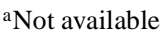


Table 2 Results of the sum calibration of the ${ }^{14} \mathrm{C}$ ages of samples from the individual groups of the Baden Culture

\begin{tabular}{|c|c|c|c|c|}
\hline Group name & $\begin{array}{l}\mathrm{Nr} \text { of } \\
\text { samples }\end{array}$ & $\begin{array}{l}\text { Baden Culture } \\
\text { phase }\end{array}$ & $\begin{array}{l}68.2 \% \text { - time interval } \\
\text { of sum calibration }\end{array}$ & $\begin{array}{l}95.4 \% \text { - time interval } \\
\text { of sum calibration }\end{array}$ \\
\hline $\begin{array}{l}\text { Sturovo- } \\
\text { Protoboleraz }\end{array}$ & 7 & Ia & $\begin{array}{l}3630 \mathrm{BC}(14.1 \%) 3580 \mathrm{BC} \\
3540 \mathrm{BC}(54.1 \%) 3360 \mathrm{BC}\end{array}$ & $\begin{array}{l}3750 \mathrm{BC}(94.3 \%) 3300 \mathrm{BC} \\
3250 \mathrm{BC}(1.1 \%) 3100 \mathrm{BC}\end{array}$ \\
\hline Boleraz & 27 & Ib-Ic-IIa & $\begin{array}{l}3640 \mathrm{BC}(46.0 \%) 3490 \mathrm{BC} \\
3470 \mathrm{BC}(4.2 \%) 3450 \mathrm{BC} \\
3440 \mathrm{BC}(17.9 \%) 3370 \mathrm{BC}\end{array}$ & $3700 \mathrm{BC}(95.4 \%) 3350 \mathrm{BC}$ \\
\hline Cerveny Hradok & 5 & $\mathrm{IIb}$ & $\begin{array}{l}3510 \mathrm{BC}(22.1 \%) 3430 \mathrm{BC} \\
3380 \mathrm{BC}(19.8 \%) 3300 \mathrm{BC} \\
3240 \mathrm{BC}(26.3 \%) 3100 \mathrm{BC}\end{array}$ & $3550 \mathrm{BC}(95.4 \%) 2900 \mathrm{BC}$ \\
\hline Ossarn I & 25 & III & $\begin{array}{l}3350 \mathrm{BC}(64.4 \%) 3010 \mathrm{BC} \\
2980 \mathrm{BC}(1.6 \%) 2960 \mathrm{BC} \\
2950 \mathrm{BC}(2.2 \%) 2930 \mathrm{BC}\end{array}$ & $3500 \mathrm{BC}(95.4 \%) 2500 \mathrm{BC}$ \\
\hline Ossarn II & 5 & IVa & $\begin{array}{l}3350 \mathrm{BC}(6.9 \%) 3310 \mathrm{BC} \\
3240 \mathrm{BC}(11.6 \%) 3170 \mathrm{BC} \\
3160 \mathrm{BC}(49.6 \%) 2870 \mathrm{BC}\end{array}$ & $3400 \mathrm{BC}(95.4 \%) 2700 \mathrm{BC}$ \\
\hline
\end{tabular}

Table 3 Sum calibration for the southeastern parallel cultures

\begin{tabular}{lclll}
\hline Group name & $\begin{array}{l}\text { Nr of } \\
\text { samples }\end{array}$ & $\begin{array}{l}\text { Baden Culture } \\
\text { phase }\end{array}$ & $\begin{array}{l}68.2 \% \text { - time interval } \\
\text { of sum calibration }\end{array}$ & $\begin{array}{l}95.4 \% \text { - time interval } \\
\text { of sum calibration }\end{array}$ \\
\hline Ezero XIII-VII & 7 & I & $\begin{array}{l}3090 \mathrm{BC}(2.1 \%) 3060 \mathrm{BC} \\
\text { 3030 BC }(41.8 \%) 2840 \mathrm{BC}\end{array}$ & $3350 \mathrm{BC}(95.4 \%) 2450 \mathrm{BC}$ \\
& & & $2820 \mathrm{BC}(24.3 \%) 2670 \mathrm{BC}$ & \\
Sitagroi & 7 & $\mathrm{I}$ & $3330 \mathrm{BC}(17.1 \%) 3220 \mathrm{BC}$ & $3550 \mathrm{BC}(95.4 \%) 2650 \mathrm{BC}$ \\
& & & $3180 \mathrm{BC}(2.6 \%) 3150 \mathrm{BC}$ & \\
Cernavoda I & 4 & $?$ & $3120 \mathrm{BC}(48.5 \%) 2880 \mathrm{BC}$ & \\
\hline
\end{tabular}

The time intervals determined by sum calibration for the southeastern parallel cultures indicate that the Ezero and the Sitagroi Cultures-formerly synchronized with the Boleráz period—should be paralleled with the phases of the Classical Baden Culture. The sum calibration of the data from the Cernavoda I Culture gives a relative large time span, which is coeval with the whole Baden period, i.e. the Baden Boleráz and the Baden Classic period.

\section{CONCLUSION}

We can deduce the following about the chronological sequence of these cultures, based on the sum calibration results of the ${ }^{14} \mathrm{C}$ data from the individual phases of the Baden culture.

1. The Boleráz period cannot be distinguished from the Proto-Boleráz period by the sum calibration of the available ${ }^{14} \mathrm{C}$ dates. For the Šturovo-Proto-Boleráz the same time period was determined as for the Boleráz Culture. The younger phases of the Baden-Classical period (III and IVa) can be well distinguished from the Boleráz period.

2. The data from Cernavoda indicate that already the Cernavoda I period was coeval with the Baden culture. Previously, the Cernavoda III period was assumed to be contemporary with the Boleráz period, and according to archaeological evidence, the Cernavoda III period was later than Cernavoda I (Roman 1999). Thus, if the older Cernavoda I period is coeval with the Baden Culture, the subsequent Cernavoda III phase cannot be associated with the Boleráz time. It must 
be noted that the Cernavoda I-III-II sequence may be verified in the future. The analysis of the Cernavoda I data is very tentative, because only four ${ }^{14} \mathrm{C}$ dates (three of them determined in the 1960s) exist for this culture. For the Cernavoda II and III phases, no age determinations are available. Therefore, more ${ }^{14} \mathrm{C}$ data are urgently needed for a better chronological assessment of the Cernavoda phases. New typological investigations reconfirm the connection between Boleráz and Cernavoda III (Nĕmejcová-Pavúková 1999).

3. The two other cultures from southeast Europe, Ezero XIII-VII and Sitagroi IV, seem to be parallel to the Baden Classical culture.

The problem of synchronizing the Sitagroi phase IV with the Boleráz stage of the Baden Culture, and of synchronizing Sitagroi Va and b with the Classical Baden is described by Breunig (1987). The ${ }^{14} \mathrm{C}$ data from both Sitagroi stages were too young for this synchronization, which was established by Nĕmejcová-Pavúková (1981). Breunig also pointed out that difficulties arise in the synchronization of Cernavoda III and Ezero XIII-VII with the Boleráz phase when the ${ }^{14} \mathrm{C}$ ages (only a few at this time) are considered.

According to these results it seems that-against former assumptions-the Baden Culture developed in central Europe and spread to the southeastern parts of Europe. The idea of a west-east spread of the Baden culture is also supported by the assumption of Maran (1998). However, before jumping to definite conclusions, more data for the southeastern groups are needed to verify our results. If this hypothesis is true, it would lead to a completely new view of the rate of cultural exchange along the Danube valley, and as another consequence, the theory that wheeled vehicles developed in the Middle East should be scrutinized.

\section{ACKNOWLEDGMENT}

This work was supported by the Austrian Science Fund, Project P12253-PHY: "Absolute Chronology for Early Civilizations in Austria and Central Europe using ${ }^{14} \mathrm{C}$ Dating with Accelerator Mass Spectrometry".

\section{REFERENCES}

Alram-Stern E. 1996. Die ägäische Frühzeit 2. Serie. Forschungsbericht 1975-1993, Veröffentlichungen der mykenischen Kommission, Bd 16, Österr. Akad. Wissensch. In German.

Barna J. 2000. Késó rézkori település NagykanizsaBilla lelöhelyen. Late Copper Age settlement at Nagykanizsa - Billa site. Zalai Múzeum 10. In preparation.

Bogucki PI. 1992. Poland. In: Ehrich RW, editor. Chronologies in Old World archaeology. Vol. I-II. Third edition. Chicago: University of Chicago Press. p 334 40.

Böhm H. 2000. Neue Funde der Badener Kultur aus Girm, Mittelburgenland. Tagungsband des Kolloquiums über die Chamer Kultur im Institut für Ur- und Frühgeschichte der Univ. Erlangen. Forthcoming. In German.

Bojadžiev J. 1992. Probleme der Radiokohlenstoffdatierung der Kulturen des Spätneolithikums und der Frühbronzezeit. Studia Praehistorica 11-12:389406.

Breunig P. 1987. ${ }^{14}$ C-chronologie des vorderasiatischen, südost- und mitteleuropäischen Neolithikums. Köln-
Wien: Böhlau Verlad. 316 p. In German.

Bronk Ramsey C. 2000. The OxCal Program v3.4. URL: http://www.rlaha.ox.ac.uk/orau/index.htm.

De Capitani A, Leuzinger U. 1998. Arbon Bleiche 3, Siedlungsgeschichte, einheimische Traditionen und Fremdeinflüsse im Übergangsfeld zwischen Pfyner und Horgener Kultur. Jahrbuch der Schweizerischen Gesellschaft für Urgeschichte 81:237-49. In German.

Ehrich RW, editor. 1992. Chronologies in Old World archaeology. Volume I-II. Third edition. Chicago: University of Chicago Press.

Foltiny S. 1959. The oldest representations of wheeled vehicles in central Europe. American Journal of Archaeology 63:53.

Forenbaher S. 1993. Radiocarbon dates and absolute chronology of the central European Early Bronze Age. Antiquity 67(255):218-56.

Görsdorf J, Bojadžiev J. 1996. Zur absoluten Chronologie der bulgarischen Urgeschichte. Eurasia Antiqua 2: 105-73. In German.

Heiling-Schmoll I. 1985. Grabungsbefund und Datierung des jungneolithischen Calvariums aus Zill- 
ingtal. Wiss. Arbeiten aus dem Burgenland 71:28-36. In German.

Kalicz N. 1963. Die Péceler (Badener) Kultur und Anatolien. Studia Archaeologica II. In German.

Kalicz N. 1976. Ein neues Wagenmodell aus der Umgebung von Budapest. Archaeologia Austriaca, Beiheft 13:188-202. Festschrift R Pittioni. In German.

Kalicz N. 1991. Beiträge zur Kupferzeit im ungarischen Transdanubien. Saarbrücker Beiträge 55/1:347-87. In German.

Krenn-Leeb A. 1991/1992. Neolithische Siedlungen und bronzezeitliche Gräber in Grub an der March. Fundberichte aus Österreich 30:30-1. In German.

Lauermann E. 1996. Eine interessante Mehrfachbestattung aus Niederhollabrunn. Archäologie Österreichs 7(1):29-31. In German.

Law IA, Hedges REM. 1989. A semi-automated bone pretreatment system and the pretreatment of older and contaminated samples. Radiocarbon 31(3):247-53.

Maran J. 1998. Die Badener Kultur und der ägäisch-anatolische Bereich. Germania 76/2:497-525. In German.

Mayer Ch. 1995a. Die Stellung der Funde vom Grasberg bei Ossarn im Rahmen der Badner Kultur. Mitteilungen der Prähistorischen Kommission der Österreichischen Akademie der Wissenschaften. 30 p. In German.

Mayer Ch. 1995b. Klassische Badner Kultur. In: Eva Lenneis, Christine-Neugebauer Maresch, Elisabeth Ruttkay, editors. Jungsteinzeit im Osten Österreichs. Wissenschaftliche Schriftenreihe Niederösterreich, Heft 102-5:161-77. In German.

Morintz S, Roman PI. 1968. Aspekte des Ausgangs des Äneolithikums und der Übergangsstufe zur Bronzezeit im Raum der Niederdonau. Dacia 12:45128. In German.

Němejcová-Pavúková V. 1981. Načrt periodizácie Badenskej kultúry a jej chronologichých vzatov k ju hovýchodnej Europe. Slovenská Arch. 29:261-96. In Slovak.

Němejcová-Pavúková V. 1984. K problematike trvania a konca bolerázkej skupiny na Slovensku. Slovenská Arch. 32:75-146. In Slovak.

Nĕmejcová-Pavúková V. 1998. Die Badener Kultur. In: Preuß J, editor. Das Neolithikum in Mitteleuropa 1/2 383-400. In German.

Nĕmejcová-Pavúková V. 1999. Bemerkungen zur Frühbronzezeit in Westbulgarien und Nordgriechenland (Im Lichte der "Importe" aus dem Karpatenbecken). Slovenská Arch. XLVII-1:41-65. In German.

Neugebauer Ch, Neugebauer JW. 1998. Franzhausen, das frühbronzezeitliche Gräber-feld I. Fundberichte aus Österreich, Materialheft A5/2. In German.

Nevizánsky G, Točík A. 1984. Predbenźné výsledki pred stihového zachranného výskumu v Bajči-Vlkanove. AVANS 1983:156-8. In Slovak.

Pavelčík J. 1992. Príspevek k absolutnímu datování osady lidu s kanelovanou keramikou v Hlinsku u Lip- níka nad Bečavou. Casopis slezského zemského muzea, Série B41:193-5. In Czech.

Pavelčík J. 1993. Keramika horizontu I z Hlinska u Lipníku nad Becvou. Pravek 3:79-141. In Czech.

Probst E. 1999. Deutschland in der Steinzeit. Munnich: Orbis-Verlag. In German.

Puchegger S, Rom W, Steier P. 2000. Automated evaluation of ${ }^{14} \mathrm{C}$-measurements. Nuclear Instruments and Methods in Physics Research. In press.

Renfrew C. 1971. Sitagroi, radiocarbon and the prehistory of south-east Europe. Antiquity 45/180:275-82.

Renfrew C. 1986. Sitagroi in European prehistory. In: Renfrew C, Gimbutas M, Elster ES, editors. 1986 Excavations at Sitagroi I. Los Angeles. p 477-85.

Roman P. 2000. Die Cernavoda-III Kultur an der Unteren Donau. Cernavoda III-Boleráz. Ein vorgeschichtliches Phänomen zwischen Oberrhein und der Unteren Donau, Mangalia. Proceedings of the Symposium Cernavoda III. Boleráz, Romania. In press. In German.

Ruttkay E. 1971. Neolithische und bronzezeitliche Siedlungsreste in Schwechat, p.B. Wien-Umgebung, NÖ. Archaeologia Austriaca 50:21-67. In German.

Ruttkay E. 1995. Spätneolithikum. In: Lenneis E, Neugebauer-Maresch Ch, Ruttkay E, editors. Jungsteinzeit im Osten Österreichs. Wissenschaftliche Schriftenreihe Niederösterreich. Heft 102-5:108-60. In German.

Ruttkay E. 1998. Fundberichte aus Österreich. 37 p. In German.

Stadler P, Draxler S, Friesinger H, Kutschera W, Priller A, Rom W, Steier P, Wild EM. 2000. Absolute chronology for early civilisations in Austria and central Europe using ${ }^{14} \mathrm{C}$ dating with accelerator mass spectrometry with special results for the absolute chronology of the Baden culture. Proceedings of the Symposium Cernavoda III. Boleráz, Romania. Forthcoming.

Schappelwein Ch. 1994. Stillfried-Auhagen. Fundberichte aus Österreich 33:496. In German.

Stuiver M, Polach HA. 1977. Discussion: reporting of ${ }^{14} \mathrm{C}$ data. Radiocarbon 19(3):355-63.

Szabó JJ. 1983. Kesô rézkori telep és közepkori falu leletmentése Gyöngyöshalász határában. Egri Múzeum Évkönyve 1983:5-17. In Hungarian.

Szabó JJ. 1997. Szihalom-Sóhajtó. Régészeti Füzetek I 49:27. In Hungarian.

Torma I. 1973. Die Boleráz-Gruppe in Ungarn. Proceedings: Symposium über die Entstehung und Chronologie der Badener Kultur. Bratislava. p 483-512. In German.

Wewerka B. 1995. Die Grabung Straß im Straßertale. In: Bericht zu den Ausgrabungen des Vereins ASINOE im Projektjahr 1994/95, FÖ 33. p 216-9. In German.

Wild E. Golser R, Hille P, Kutschera W, Priller A, Puchegger S, Rom W, Steier P, Vycudilik W. 1998. First ${ }^{14} \mathrm{C}$ results from archaeological and forensic studies at the Vienna Environmental Research Accelerator. $R a$ diocarbon 40(1):273-81. 